Policy Forum

\title{
Oil Palm Plantations, Forest Conservation and Indigenous Peoples in West Papua Province: What Lies Ahead?
}

\author{
Yubelince Y. Runtuboi ${ }^{1,3}$, Dwiko B. Permadi ${ }^{1}$, Muhammad Alif K. Sahide ${ }^{2}$, Ahmad Maryudi ${ }^{1}$ \\ 1 Sebijak Institute - The research Center for Forest Policy \& History, Faculty of Forestry, Universitas Gadjah \\ Mada, Yogyakarta, Indonesia \\ 2 Universitas Hasanuddin, Makassar, Indonesia \\ 3 Universitas Papua, Manokwari, Indonesia \\ * Correspondence author: yruntuboi@gmail.com ; Tel.: +6281386038118
}

\begin{abstract}
Oil palm plantations are currently expanding to the eastern part of Indonesia, especially into West Papua province. Many oil palm permits issued in West Papua occupy intact biodiversity-rich forest areas which have essential value for indigenous Papuans' socio-cultural life. This article discusses expansion of oil palm plantations in West Papua province, and its impacts on forests and indigenous people. It also assesses whether the plantations fit the Special Autonomy Law and Sustainable Development Regulation goals of the province. In general, plantations are being established in forest areas, and further planned expansion threatens intact and biodiversity-rich forests. In addition, plantation development rarely considers the sociocultural issues of indigenous Papuans. As a result, customary rights and institutions are commonly overlooked, undermined, or violated. Oil palm plantations are not necessarily compatible with sustainable development goals, and need to reconcile its overall economic and conservation agenda.
\end{abstract}

Keywords: Oil Palm Plantation; Special Autonomy Law; Sustainable development policy; West Papua; Indigenous People; Poverty alleviation; Conservation; Biodiversity loss

\section{Introduction}

Oil palm plantations are expanding rapidly in Indonesia (Andrianto, et al., 2019; Purnomo, et al., 2020; Ramdani \& Lounela, 2020). As of 2018, the total area of oil palm plantations reached nearly 15 million hectares (Directorate General of Estate Crops, 2019). This is mainly driven by increasing demands on palm oil in global markets (Lambin \& Meyfroidt, 2011). Over the past few years, palm oil has become a main export commodity, and played an important role in Indonesia's economy (Purba \& Sipayung, 2018; Santika, et al., 2019). In fact, Indonesia has become the world's largest producer of palm oil (Afriyanti, et al., 2016; PASPI, 2018). Plantations are expected to further increase over the next few years (Setiawan, et al., 2016). Planting areas are now expanding rapidly into to eastern Indonesia (Susanti \& Maryudi, 2016). The Directorate General of Estate Crops (2019) now indicates that Sulawesi and Papua (Papua and West Papua Provinces) have substantial land areas targeted or allocated for plantation expansion.

This paper discusses oil palm expansion in West Papua Province, and analyzes the potential adverse impacts on frontier forests. With a percentage of forest cover $>75 \%$ in West Papua Province, oil palm plantations will inevitably focus on transforming lowland forest areas into cultivated areas (Gaveau, 2019; Namkhan, et al., 2020; Susanti \& Maryudi, 2016). This paper further discusses what oil palm expansion means for a province that has pledged to pursue ambitious conservation plans to review current land-use concessions. In fact, the provincial government has stated in the "Manokwari Declaration" that a minimum of $70 \%$ of its land area will be set aside for protection areas, while improving livelihoods of indigenous communities through sustainable development (Cámara-Leret, et al., 2019). More importantly, this paper assesses what special autonomy means 
for West Papua, as the province is confronted with two major issues, namely development pressure and local rights recognition pressure (Fatem, et al., 2018). This paper argues that oil palm expansion, in the name of development, will continue to be a driving force for the exclusion and insecurity of indigenous Papuans. At the end of this paper, we propose ways to accommodate local interests, including ways to consider integrating locally-adapted social forestry schemes.

\section{Oil Palm Expansion in West Papua's Forests}

West Papua province has a total forest area of nearly 9 million hectares (Dinas Kehutanan Provinsi Papua Barat, 2020), consisting mostly of intact forests with considerable diversity of genotypes, species, ecosystems, and landscapes (Cámara-Leret, et al., 2020). The (state) forest area makes up approximately $97 \%$ of the province's land area (Dinas Kehutanan Provinsi Papua Barat, 2020). According to the forest classification by the Ministry of Environment and Forestry, $56 \%$ of the forests are gazetted for production purposes (including 15.2\% for conversion), while the remaining is allocated for conservation and protection. West Papua province, along with other regions in New Guinea Island, is considered a region with the world's largest biodiversity (Cámara-Leret, et al., 2020). Quite often, the forests are seen as the last frontiers. Thus, forest conservation is crucial in the contexts of global biodiversity conservation as well as climate change mitigation.

Over the past few years, the forests of West Papua have been targeted for exploitation, including conversions for oil palm (Gaveau, 2019). Oil palm plantations in West Papua province have grown in recent years and are a manifestation of Indonesia's national food security and economic development policies. Oil palm plantations were first established in West Papua province in 1986 (Matualage, et al., 2019) and plantation areas have since expanded rapidly. Many oil palm company licenses in forest areas were set aside between 2009 - 2015, most of which had obtained forest release decrees (Dinas Kehutanan Papua Barat, 2020). As of 2020, there are eighteen plantation concessions covering a total area of 321,370 hectares, approximately $80 \%$ of which are within forest zones, on both intact forests and ex-logging concessions (Dinas Kehutanan Provinsi Papua Barat, 2020). In addition, newer plantations are planned for establishment in forest zones of 290,100 hectares distributed to 9 companies (Dinas Kehutanan Provinsi Papua Barat, 2020). The total plantation area might be considered as modest relative to the total forest area of West Papua. However, there are growing concerns among customary communities, local governments, civil society organizations, about the rate at which oil palm plantations are expanding (Elizabeth, 2020; Indrawan, et al., 2019). More than 50\% of the total plantations have been developed in the past 11 years (Dinas Kehutanan Provinsi Papua Barat, 2020). Most of these plantations are located in flat and intact lowland rainforest areas ( $<700$ masl) known to be areas of high biodiversity. In light of this, the biodiversity of lowland forests, including woody and non-woody plants, mammals (Timor deer, tree kangaroos), birds (cockatoo species, parrot species) are most at risk.

As is the case in many other regions (see Setiawan, et al., 2016), licensing of oil palm plantations in West Papua are often problematic in terms of legal procedures, e.g. bypassing the release of the areas from forest zones. In addition, environmental impact assessments are often non-existent (Jubi, 2019; KPK, 2020). Existing plantations have compromised forest quality and biodiversity since most of them were established in forest zones. As the central government is gearing up further expansion of oil plantations in West Papua province, intact lowland forests with rich biodiversity are likely to come under immense pressure (Dinas Kehutanan Provinsi Papua Barat, 2020; Namkhan, et al., 2020).

\subsection{Plantations and Local-Customary Communities}

The forests of West Papua have long held an important position as living space for various tribes and indigenous communities (Forest Watch Indonesia, 2019). Formally, the forests of West Papua are controlled under central state authority. Nonetheless, there are strong customary claims over 
state forests in West Papua and Papua Provinces, well-known as Tanah Papua in general, under the contexts of Tanah Adat or Tanah Ulayat (customary land) ${ }^{1,2}$. Regional special autonomy stipulated in Law No. 21/ 2001 and Law No. 35/ 2008 acknowledges the unique institutions and systems of authority in Papua compared with other provinces in Indonesia, and therefore also opens up opportunities for the recognition of customary rights and institutions. The position of customary claims on forests in Papua was also further enhanced by the Decision of the Constitutional Court No. 35/ 2012, which ruled that customary forests are no longer included as state forests (Myers, et al., 2017). However, the implementation of new regulations remains unclear in West Papua. For instance, customary land is insufficiently elaborated in the Special Autonomy Law, resulting in confusion and or various interpretation which can then be misused or ignored by other parties. It is only mentioned twice in the Law concerning the provision of land for development purposes and with respect to land dispute resolution without a clear definition on the scope of customary land as an object of customary right. In addition, the terms of customary forests and customary villages are largely non-existent in the Law, despite the fact that most of the villages and forests used by indigenous Papuans lie on customary land. This means that, when faced with national policies such as social forestry, this local tenure needs some adjustments to meet the requirements of state legislation.

There have been problems related to customary lands during the past three-decades of plantation development in West Papua. Indigenous Papuan rights have rarely been taken into consideration in the decision-making process for the use of customary land. The issuance of oil palm permits and the provision of investment facilities for corporations were carried out without the consent of indigenous peoples, which results in frequent protests when plantation companies begin to initiate their operations (Ito, et al., 2014; Savitri \& Price, 2016). Negotiations typically take place after decisions have been made, leaving indigenous communities with limited choice. Indigenous communities rarely had a say in negotiation processes with plantation companies; they were not provided with opportunities to exercise options without pressure, whether to accept or reject the plantation operations (Chao, 2019; Jubi, 2019). In most cases, the release of customary lands for plantations only involve pro-clan elites and rarely includes broader consultation of buy-in among other clan members who can also be adversely affected by the eventual plantation operations. In West Papua, there are diverse customary land-forest arrangements which do not necessarily fit with the national regulatory systems governing land (Fatem, 2019; Ungirwalu, et al., 2017, 2019) and often lack strong legal support in national development policies that favor oil palm plantation. Local tenure arrangements are therefore frequently overlooked during the processes. For example, the customary rules of indigenous Papuans require that other parties wishing to use customary land must first seek permission from the customary landowner. However, oil palm companies frequently disregard this aspect.

Even when agreements were struck, there have also been concerns about the distribution of benefits among indigenous peoples (Albert, 2019; Fatem et al., 2020b; Samperante, 2018). Protests against plantation investments are not uncommon (see Table 1.).

\footnotetext{
${ }^{1}$ In the social life of the people of Papua, the usage of the term customary land is the same as that of the term ulayat land, and these two terms are generally used interchangeably. This is also the case with the term customary right and ulayat rights, often used interchangeably but with the same definition.

2 Papuan's views of Tanah Adat/Ulayat are a territory which includes land, forests, mountains, valleys, rivers, lakes, ponds, mangroves, swamps, sago hamlets, islands, and all objects above and below land, of which there are customary rights based on sub-clan/clan/sub-tribe/tribe.
} 
Table 1. Local community - company conflict in West Papua Province

\begin{tabular}{lll}
\hline No. & & Location \\
\hline 1 & Mpur Tribe vs PT. Bintuni Agro Prima Perkasa & Kebar Valley, Tambrauw District \\
2 & $\begin{array}{l}\text { Customary community of MooiKelim vs PT. } \\
\text { Mega Mustika Plantation }\end{array}$ & Klasso Valley, Sorong Regency \\
3 & $\begin{array}{l}\text { The tribe of Iwaro and Awe vs PT. Permata } \\
\text { Putra Mandiri }\end{array}$ & Metemani, Sorong Selatan Regency \\
4 & $\begin{array}{l}\text { The tribe of Wandamen, Torowar and } \\
\text { Mairasi vs PT. Menara Wasior }\end{array}$ & Teluk Wondama Regency \\
5 & PT Mitra Silva Lestari and Sougb tribe & Tahota sub-district, Manokwari selatan regency \\
\hline
\end{tabular}

Indigenous peoples' claims about the expansion of oil palm plantations in West Papua Province amount to a forced enclosure of land use (land grabbing), which also results in losses of forest resource potential as a vital element of survival for local lives and livelihoods. Indigenous Papuans experiencing loss of access to land result in scarcity of traditional foods, loss of livelihoods, loss of settlements, and loss of socio-cultural attachments. There has been no serious attention given to the involvement of indigenous Papuans in oil palm plantations, although the socio-economic and cultural ties of indigenous Papuans to the area of oil palm production are very significant.

At best, indigenous communities are provided with partnership schemes (nucleus arrangements $)^{3}$ and employment opportunities by plantation companies. For instance, PTPN II, a government plantation company operated in Manokwari since 1986, has been running oil palm plantations through partnerships with both transmigrants and local people. Nonetheless, the thirtyyear experience of Manokwari oil palm plantation indicates only a small portion (10\%) of the nucleus plantations is managed by local people (Matualage, et al., 2019). Plantation companies in most cases prefer migrant laborers to local people, due to the perceived lack of skills of the locals in managing plantations. The study by Matualage et al. (2019) also points out the lower incomes that local farmers receive compared to transmigrants.

\section{Plantations and Sustainable Development Pledges}

Empowered by the special autonomy laws and regulations, the provincial government of West Papua has issued Special Regional Regulations for Sustainable Development which aim to reconcile goals of local economic development and empowerment, and natural resource conservation and protection. The core goals include poverty alleviation, enhancing community health, maintaining indigenous Papuans' rights, sustainable management of forests, as well as prevention of forest and biodiversity losses in West Papua. The province has pledged to set aside $70 \%$ of its land as protection areas, which followed by a review process for the current oil palm concession and mining license as a material for consideration in the process of revision of the West Papua Spatial Plan. This is an ambitious target and in the current context will be quite challenging to achieve. Approximately 3 million hectares, or more than a third of the province's land area has been used or designated under economic development purposes, i.e. as oil palm and other estate plantations, logging concessions and slated for conversion (Dinas Kehutanan Provinsi Papua Barat, 2020). This figure does not include areas designated for road infrastructure, which is likely to result in additional dramatic changes under the Trans Papua development plan.

Excessive opening of a relatively intact forest area for oil palm plantations and further planned expansions have been a source of high concern for local government and local communities (Acosta \& Curt, 2019; Chao, 2019). Over the past few years oil palm plantations have been increasingly

\footnotetext{
3 The palm oil company managed plasma plantations (nursery, planting, maintenance) until the oil palm plantations were four years old and subsequently handed over to plasma farmers.
} 
considered as bad actors undertaking plans and practices in bad faith at the local level (province and district), as evidenced from the many environmental and socio-cultural problems associated with their approaches and operations (Hadiprayitno, 2015; Ito, et al., 2014). As a result, as part of their conservation and protection commitments, local governments promised to implement an oil palm moratorium policy (Cámara-Leret, et al., 2019). The local governments also started to review plantation permits during the ongoing revision of the West Papua Provincial Spatial Plan to limit the excessive expansion of oil palm. For example, PT Bintuni Agro Prima Perkasa, which obtained an oil palm permit for the conversion of the forest area of the Kebar Valley (Tambrauw Regency) is being encouraged to change the commodity to food crops. The local government further proposed a scenario to increase the status of undeveloped oil palm plantation areas (cultivation area) considered as ecological corridors to become a protected area as proposed under the Provincial Strategic Area "Mahkota Permata Papua" (Tabura Pos, 2019).

The special autonomy regulations also emphasize the importance of acknowledging sociocultural conditions of indigenous peoples. The development objective is to accelerate the improvement of welfare in West Papua Province (Pakasi, 2012; Fatem et al., 2020a). One of the main explanations of the local regulations and initiatives is that the management and development of rich natural resources have destroyed the resources that are vital to the survival of indigenous Papuans, and the terms of engagement offer unfair arrangements for local welfare (Acosta \& Curt, 2019; Baransano, et al., 2016; Matualage, et al., 2019). What is evident from the practices of oil palm plantations in West Papua province, however, raises several issues that are not deemed to improve the wellbeing of indigenous Papuans. This has led to several cases in which indigenous Papuans initially accepted the presence of oil palm plantations but later turned against them. Protests against oil palm plantations have increased by reconstructing the indigenous Papuan's way of thinking of protecting customary land after witnessing the impacts among intact forests. Oil palm expansion is thus viewed as further undermining the Special Autonomy Law and the special regulation on Sustainable Development of the West Papua Province, particularly with regard to issues of exclusion, marginalization, and discrimination of indigenous peoples.

\section{Conclusions}

At the national level, oil palm development is positioned as one of the core strategies for reducing poverty and reforesting unproductive lands. At the local level, however, it is a driving force behind pervasive poverty, violation of rights of indigenous Papuans, and deforestation. Although oil palm plantations contribute to the absorption of labor and the availability of sources of income, they cannot replace the value of forests for indigenous peoples who still have ecological, social and cultural ties to forest and land areas (Acosta \& Curt, 2019; Matualage, et al., 2019). The development of oil palm under the pretext of poverty alleviation therefore tends to jeopardize the role, authority, and the overall existence of indigenous Papuans. This has resulted in customary land enclosures, violations of customary rights and the ecological, economic, and socio-cultural burdens that indigenous peoples are facing as a result of the loss of forest and land resources.

Oil palm expansion in West Papua province has increasingly been deemed as undermining the goals laid out in the Special Autonomy Law. The rapid growth of oil palm in West Papua is not accompanied by good governance, recognition, and capacity building of indigenous Papuans. This implies that the implementation of the oil palm industry in West Papua as a driver of economic growth needs to be examined more deeply without the rush to define priority options that comply with the mandates of the Special Autonomy Law. Natural resource management schemes, including development of oil palm plantations, should address fairness and justice issues, not only the distribution of benefits but also the process with which local contexts are sufficiently acknowledged. This can be achieved by carefully updating natural resource management policies in the process of revising the existing Special Autonomy Law for its second phase of implementation in West Papua 
province. Thirty years of experience in oil palm plantations should be a benchmark in policy-making that can reconcile issues of the economy, conservation and socio-culture dimensions of indigenous Papuans.

Ideally, oil palm expansion policy in West Papua should take into account the unique ecological, economic and socio-cultural conditions, so that it can be equally beneficial not only to external investors and government institutions but also to the indigenous people of Papua. For example, the rapid oil palm plantation has hindered the process of matching customary forests in Papua with existing formal governance schemes. To be consistent with the context of West Papua province, management scenarios should recognize West Papua's unique condition and local interests. Social forestry through the customary forest scheme suits West Papua's contexts, but not a single customary forest permit has been issued to date. This is due to the simplistic interpretation of the central government on what customary forests are, or what they should be. In fact, the central government continues to push forward village forests and community forests, which both fall under state forest zone categorizations. Given this context, we predict that in the future, oil palm expansion will continue to be a driving force for the exclusion and insecurity of indigenous Papuans. Likewise, it will remain a threat to the intact biodiversity-rich forest zones of West Papua. If the central government does not push the implementation of the Special Regional Regulations for Sustainable Development in West Papua Province, then Indonesia's Papua's remaining intact forests will experience pressure, decline and degradation.

\section{Acknowledgments}

The research is funded by a BUDI-LPDP scholarship from the Ministry of Finance of the Republic of Indonesia. The writing of this paper was facilitated by the Rekognisi Tugas Akhir (RTA) Program of Universitas Gadjah Mada in 2020. We would like to thank editors and reviewers for providing valuable inputs on our manuscript.

\section{Conflicts of Interest}

The authors declare there is no risk of conflict of interest.

\section{References}

Acosta, P., \& Curt, M. D. (2019). Understanding the expansion of oil palm cultivation: A case-study in Papua. Journal of Cleaner Production, 219, 199-216. https://doi.org/10.1016/J.JCLEPRO.2019.02.029

Afriyanti, D., Kroeze, C., \& Saad, A. (2016). Indonesia palm oil production without deforestation and peat conversion by 2050. Science of The Total Environment, 557-558, 562-570. https://doi.org/10.1016/J.SCITOTENV.2016.03.032

Albert. (2019). Dishut Papua Barat Buka Kedok Status PT. BAPP di Lembah Kebar Tambrauw | Mobile Wartaplus.com. Retrieved August 14, 2020, from https://www.m.wartaplus.com/read/6321/Dishut-Papua-Barat-Buka-Kedok-Status-PTBAPP-di-Lembah-Kebar-Tambrauw

Andrianto, A., Komarudin, H., \& Pacheco, P. (2019). Expansion of Oil Palm Plantations in Indonesia's Frontier: Problems of Externalities and the Future of Local and Indigenous Communities. Land, 8(4), 56. https://doi.org/10.3390/land8040056

Baransano, M. A., Putri, E. I. K., Achsani, N. A., \& Kolopaking, L. (2016). Peranan Sektor Unggulan sebagai Salah Satu Faktor dalam Mengurangi Ketimpangan Pembangunan Wilayah di Provinsi Papua Barat. Jurnal Perencanaan Wilayah Dan Kota, 27(2), 119. https://doi.org/10.5614/jrcp.2016.27.2.4

Cámara-Leret, R., David G. Frodin, D. ., Adema, F., Anderson, C., Appelhans, M. S., Guerrero, S. ., ... Welzen2, P. C. van. (2020). New Guinea has the world' s richest island. Nature 2020, (October 2019), 1-5. https://doi.org/10.1038/s41586-020-2549-5 
Cámara-Leret, R., Schuiteman, A., Utteridge, T., Bramley, G., Deverell, R., Fisher, L. A., ... Heatubun, C. (2019). The Manokwari declaration: Challenges ahead in conserving $70 \%$ of Tanah Papua's forests. Forest and Society, 3(1), 148-151. https://doi.org/10.24259/fs.v3i1.6067

Chao, S. (2019). The Plastic Cassowary: Problematic 'Pets' in West Papua. Ethnos, 84(5), 828-848. https://doi.org/10.1080/00141844.2018.1502798

Dinas Kehutanan Provinsi Papua Barat. (2020). Pengelolaan Hutan Provinsi Papua Barat.

Elizabeth, A. (2020). Evaluasi Izin Kebun Sawit di Papua Barat, Bagaimana Perkembangannya? Retrieved October 31, 2020, from https://www.mongabay.co.id/2020/09/07/evaluasi-izinkebun-sawit-di-papua-barat-bagaimana-perkembangannya/

Fatem, S. M, Syufi, Y., Baru, J., Marwa, J., Runtuboi, Y. Y., Tawer, V., ... Runtuboi, F. R. (2020a). The sausapor declaration: Challenges in promoting good governance to protect customary communities and natural resources in Tambrauw District, West Papua. Forest and Society, 4(2), 330-337. https://doi.org/10.24259/fs.v4i2.9346

Fatem, S. M., Awang, S. A., Maryudi, A., Pudyatmoko, S., \& Marwa, J. (2020b). Model Kelembagaan Lokal Kabupaten Konservasi Tambrauw di Papua Barat. Jurnal IImu Kehutanan, 14(2), 167184. https://doi.org/10.22146/JIK.61401

Fatem, S. M. (2019). Connecting social forestry to conservation policies in Tanah Papua. Forest and Society, 3(1), 141-147. https://doi.org/10.24259/fs.v3i1.5865

Fatem, S. M., Awang, S. A., Pudyatmoko, S., Sahide, M. A. K., Pratama, A. A., \& Maryudi, A. (2018). Camouflaging economic development agendas with forest conservation narratives: $A$ strategy of lower governments for gaining authority in the re-centralising Indonesia. Land Use Policy, 78, 699-710. https://doi.org/10.1016/J.LANDUSEPOL.2018.07.018

Forest Watch Indonesia. (2019). BioRegion Papua: Hutan dan Manusianya. "Hasil studi Baseline mengenai Hutan dan Manusia di Bioregion Papua." In M. F. Barri \& E. Cahyono (Eds.) (p. 250). Forest Watch Indonesia (FWI).

Gaveau, D. (2019). Drivers of forest loss in Papua and West Papua. Cifor.Org. Retrieved from https://www.cifor.org/publications/pdf_files/factsheet/7444-factsheet.pdf

Hadiprayitno, I. I. (2015). Behind Transformation: The Right to Food, Agricultural Modernisation and Indigenous Peoples in Papua, Indonesia. Human Rights Review, 16(2), 123-141. https://doi.org/10.1007/s12142-015-0353-7

Indrawan, M., Sumule, A., Wijaya, A., Kapisa, N., Wanggai, F., Ahmad, M., ... Heatubun, C. D. (2019). A time for locally driven development in Papua and West Papua. Development in Practice, 29(6), 817-823. https://doi.org/10.1080/09614524.2019.1609907

Ito, T., Rachman, N. F., \& Savitri, L. A. (2014). Power to make land dispossession acceptable: a policy discourse analysis of the Merauke Integrated Food and Energy Estate (MIFEE), Papua, Indonesia. The Journal of Peasant Studies, 41(1), 29-50. https://doi.org/10.1080/03066150.2013.873029

Jubi. (2019). Bagaimana Boven Digoel Menjadi Sasaran Perkebunan Sawit Terluas Di Dunia. Jubi. Retrieved from https://jubi.co.id/bagaimana-boven-digoel-menjadi-sasaran-perkebunansawit-terluas-di-dunia/

KPK. (2020). Pencegahan Korupsi Sektor Komoditas Kelapa Sawit. Indonesia: Greenpeace Indonesia. Retrieved from https://www.youtube.com/results?search_query=modus+tiputipu+perusahaan+sawit

Lambin, E. F., \& Meyfroidt, P. (2011). Global land use change, economic globalization, and the looming land scarcity. In Proceedings of the National Academy of Sciences of the United States of America (Vol. 108, pp. 3465-3472). National Academy of Sciences. https://doi.org/10.1073/pnas.1100480108 
Matualage, A., Hariadi, S. S., \& Wiryono, P. (2019). Pengelolaan Kebun Kelapa Sawit dalam Pola Kemitraan Inti Plasma PTPN II Prafi dengan Petani Suku Arfak Di Manokwari, Papua Barat. JSEP (Journal of Social and Agricultural Economics), 12(1), 19. https://doi.org/10.19184/jsep.v12i1.6897

Myers, R., Intarini, D., Thomas, M., \& Maryudi, A. (2017). Land Use Policy Claiming the forest : Inclusions and exclusions under Indonesia's' new forest policies on customary forests. Land Use Policy, 66(May), 205-213. https://doi.org/10.1016/j.landusepol.2017.04.039

Namkhan, M., Gale, G. A., Savini, T., \& Tantipisanuh, N. (2020). Loss and vulnerability of lowland forests in mainland Southeast Asia. Conservation Biology, cobi.13538. https://doi.org/10.1111/cobi.13538

Pakasi, U. (2012). Local Community Empowerment in the Special Autonomy Law in Papua Province. Journal of Government and Politics, 3(2), 335--350. https://doi.org/10.18196/jgp.2012.0019

PASPI. (2018). Sawit dan Kebijakan Industrialisasi Sawit Menuju 2050 | Gabungan Pengusaha Kelapa Sawit Indonesia (GAPKI). Retrieved August 19, 2020, from https://gapki.id/news/3209/sawit-dan-kebijakan-industrialisasi-sawit-menuju-2050

Purba, J., \& Sipayung, T. (2018). Perkebunan kelapa sawit indonesia dalam perspektif pembangunan berkelanjutan. Jmi.Ipsk.Lipi.Go.ld, 43(1). Retrieved from http://jmi.jpsk.lipi.go.id/index.php/jmiipsk/article/view/717

Purnomo, H., Okarda, B., Dermawan, A., Ilham, Q. P., Pacheco, P., Nurfatriani, F., \& Suhendang, E. (2020). Reconciling oil palm economic development and environmental conservation in Indonesia: A value chain dynamic approach. Forest Policy and Economics, 111. https://doi.org/10.1016/j.forpol.2020.102089

Ramdani, R., \& Lounela, A. K. (2020). Palm oil expansion in tropical peatland: Distrust between advocacy and service environmental NGOs. Forest Policy and Economics, 118. https://doi.org/10.1016/j.forpol.2020.102242

Samperante, F. (2018). Dari hutanlah kami hidup, bukan dari kelapa sawit | Drupal. Retrieved August 14, 2020, from https://www.forestpeoples.org/id/node/50232

Santika, T., Wilson, K. A., Budiharta, S., Law, E. A., Poh, T. M., Ancrenaz, M., ... Meijaard, E. (2019). Does oil palm agriculture help alleviate poverty? A multidimensional counterfactual assessment of oil palm development in Indonesia. World Development, 120, 105-117. https://doi.org/10.1016/j.worlddev.2019.04.012

Savitri, L. A., \& Price, S. (2016). Beyond special autonomy and customary land rights recognition: examining land negotiations and the production of vulnerabilities in Papua. In J. F. McCarthy \& K. Robinson (Eds.), Land and Development in Indonesia:Searching for the People's Sovereignty. ISEAS-Yusof Ishak Institute Singapore. Retrieved from https://books.google.co.id/books?hl=id\&lr=\&id=e1B3DAAAQBAJ\&oi=fnd\&pg=PA1\&dq

Setiawan, E. N., Maryudi, A., Purwanto, R. H., \& Lele, G. (2016). Opposing interests in the legalization of non-procedural forest conversion to oil palm in Central Kalimantan, Indonesia. Land Use Policy, 58, 472-481. https://doi.org/10.1016/j.landusepol.2016.08.003

Susanti, A., \& Maryudi, A. (2016). Development narratives, notions of forest crisis, and boom of oil palm plantations in Indonesia. Forest Policy and Economics, 73, 130-139. https://doi.org/10.1016/J.FORPOL.2016.09.009

Tabura Pos. (2019). KSP Mahkota Permata Papua Masuk Dalam Pembahasan Revisi RTRW Papua Barat - Tabura Pos. Retrieved August 18, 2020, from https://taburapos.com/2019/09/26/ksp-mahkota-permata-papua-masuk-dalampembahasan-revisi-rtrw-papua-barat/

Ungirwalu, A., Awang, S. A., Suryanto, P., \& Maryudi, A. (2017). The ethno-techno-conservation approach in the utilization of Black Fruit (Haplolobus sp.) by the Wandamen ethnic of Papua, 
Indonesia. Biodiversitas, Journal of Biological Diversity, 18(4), 1336-1343. Retrieved from https://smujo.id/biodiv/article/view/2063

Ungirwalu, A., Awang, S., Maryudi, A., \& Priyono, S. (2019). Small Scale Ecology and society: ForestCulture of Papua Nutmeg (Myristica argantea Warb.). Retrieved from http://repository.unipa.ac.id:8080/xmlui/handle/123456789/375 